\title{
Az új hidegháború kérdéséről
}

\section{On the Issue of the New Cold War}

Kusai Sándor Zoltán

https://doi.org/10.47707/Kulugvi_Szemle.2021.2.1

Összefoglaló: A tanulmány először munkadefiníciót fogalmaz meg a hideg háború fogalmára vonatkozóan. Összegzi e történelmi jelenség fỏ jellemzőit, felvázolja az egyes korokban kimutatható hasonlóságait és eltéréseit. Elemzi a meghatározó aktuális nemzetközi folyamatokat és trendeket, és megállapítja, hogy az új hidegháború már megkezdődött, és gyakorlatilag az első szakaszában tart. Számba veszi a második hidegháború fő- és mellékszereplőinek (az Amerikai Egyesült Államoknak és más nyugati hatalmaknak, valamint Kínának és Oroszországnak) a motivációit, törekvéseit és viselkedését, valamint áttekinti a kibontakozó küzdelem legfontosabb tartalmi frontvonalait és földrajzi hadszíntereit. Végül arra a következtetésre jut, hogy a főszereplők szándéka a küzdelem végigvitele, így a második hidegháború a következő történelmi időszak meghatározó nemzetközi tényezője marad. A szerző az új hidegháború további alapos elemzését és a vele kapcsolatos elmélyült szakmai viták indítását javasolja.

Kulcsszavak: hidegháború, Egyesüllt Államok, Európa, Kína, Oroszország

Abstract: The paper offers a working definition for the category of Cold War. It summarises the main characteristics of Cold War as a historic phenomenon. oullines it similarities and differences in particular historic periods. It analyses the most important current international processes and trends, and states that the new Cold War has already begun, and it is practically in its opening phase now. It specifies the main and secondary actors of Cold War II (the USA, other Western powers as well as China and Russia), their molivations, aspirations and behaviour, and reviews the major substantive fronllines and geographical battlefields of the unfolding struggle. Finally, it concludes that Cold War II will remain the main international factor of the next historical period. It suggests continued substantive analysis of Cold War II, and proposes further deep professional discussions on that topic.

Keywords: Cold War, United States, Europe, China, Russia 


\section{Bevezetés: az új hidegháború kérdésének felmeriilése}

A nemzetközi folyamatokkal foglalkozó tudományos és szakpolitikai irodalom, illetve a közvéleményt formáló média jelentős része egyre többet tárgyalja azt a kérdést, hogy a vezető nagyhatalmak fokozódó globális egymásnak feszülése milyen jellegű, és egy újabb hidegháborúként értelmezhető-e. A szakértői helyzetértékeléseket és előrejelzéseket a sokszínúség jellemzi, amelynek a két szélsô véleményét az új hidegháború tényének az elfogadása, illetve tagadása adja (Dupont, 2020; Fishman, 2020; Christensen, 2021; Larison, 2021; Haass és Kupchan, 2021; Zakaria, 2021). Még a globális folyamatok iránt általában kevés érzékenységet mutató magyar nyelvű publicisztikákban is több aggodalom fogalmazódik meg egy új hidegháború és annak Magyarországra vonatkozó esetleges hatásai kapcsán (Hegyi, 2021a; Hegyi, 2021b; Lehoczki, 2021; Lóránt, 2021; Guetta, 2021; Kusai, 2021; Gyarmati, 2021). A politikusok, külpolitikai irányítók, vezető diplomaták egyelőre kerülik a helyzet hidegháborúvá nyilvánítását, de veszélyként mind gyakrabban emlegetik (Ni, 2021; Munk, 2021; REV, 202la; REV, 2021b). A közkapcsolati diplomácia szabályai szerint ez természetes, hiszen az előző hidegháború összességében nem hagyott jó emlékeket a közvéleményben, ezért azt fel kell készíteni egy újnak az elfogadására.

A hidegháború kérdése szakmai szempontból egyszerre elméleti és gyakorlati jellegű, amely kiterjed a kül-, a biztonság-és a külgazdaság-politikára, az ideológiára és minden más szférára. Elvégre a történelmileg példátlanul globalizált világunkban a nemzetközi kör nyezet minden ország és csoportosulásaik - a nagyhatalmak, a közepes és a kis országok, integrációs szervezetek, katonai szövetségek és globális szerkezetek - számára meghatározó egzisztenciális tényezô.

E tanulmányban ezért e probléma néhány tényezőjére és összefüggésére kívánom felhívni a figyelmet - elméleti és gyakorlati aspektusból egyaránt -, elsősorban az elsődleges forrásokra, eredeti politikai dokumentumokra támaszkodó elemzés révén. 


\section{Külïgyi Szemle}

\section{A hidegháború lehetséges munkadefiníciója}

Mint a legtöbb esetben, az eltérő megközelítések, értékelések és viták egyik fő elméleti és módszertani forrása e kérdésben is az, hogy a hidegháborúnak nincs általánosan elfogadott tudományos definíciója. Ez természetes következménye annak, hogy az 1990-es évektől a gyakorlati külpolitika mellett a tudomány különböző irányzatai - tartozzanak akár a „„örténelem végét”, akár a „civilizációk összecsapását" hirdető iskolához, akár a kettő közötti kompromisszumkísérletek bármely formájához - egyaránt egyszeri, nem ismétlődő történelmi jelenségként kezelték az előző hidegháborút. Így kevés energiát fordítottak arra, hogy tudományos igénnyel definiálják - azaz a múlt axiomatikus elemeként kezelték. Ezért az elemzés kereteinek, értelmezési tartományának a meghatározása érdekében itt egy munkadefiníciót javaslok a hidegháború fogalmára.

A hidegháború olyan totális, hosszú ideig tartó, viszonylag békés küzdelem két vagy több nagyhatalom és a szövetségeseik, szoros partnereik, illetve az őket uraló politikai-hatalmi rendszerek és rezsimek között, amely a globális dominanciáért folyik. Ez a fagyos viszony az államok belső és nemzetközi viszonyainak minden aspektusára kiterjed - a gazdaságra, a társadalomra, a szellemi szférára, az értékrendre, az ideológiára, a bel-, kül- és biztonságpolitikára, a geopolitikára, a stratégiára és a fegyverkezésre, továbbá a világrendre, a nemzetközi rendszerre, a globális és regionális kormányzásra ${ }^{1}-$, de nem jelent a szemben álló felek közti közvetlen, nyílt fegyveres összecsapást (világháborút). Mindkét oldal végső célja a teljes győzelem, amely az ellenfél globális nagyhatalmi pozíciójának a megszüntetését, de legalábbis a globális befolyásának a visszaszorítását, a hatalmi alárendelését és a politikai-hatalmi rezsimjének a felszámolását jelenti.

1 A világrend, a nemzetközi rendszer és a globális kormányzás fogalmának - a hidegháborúhoz hasonlóan - nincs általánosan elfogadott tudományos definíciója. Ezért itt e fogalmakat is munkadefiníciók keretében értelmezem (Kusai 2020a). 
A hidegháború csak azért nem világháború, mert a tömegpusztító fegyverek korában az utóbbi kivitelezhetetlen anélkül, hogy végkifej letként a győztes fél is ne semmisüljön meg, vagy ne szenvedjen elviselhetetlen mértékủ veszteségeket. A hidegháború tehát valójában nem más, mint a vezetổ nagyhatalmak közötti feloldhatatlan ellentétek megoldásáert folytatott harcnak az objektív kényszerbő́l előáltt, viszonylag békés formája abban a történelmi korban, amelyben a korábban szokásos, fegyveres erỏvel - a 20. században világháborúval - történt megoldása ellehetetlenült. Természetesen a globális nagyhatalmak ma is keresik annak a lehetőségét, hogy visszatérjenek a feloldhatatlan ellentéteik jól megszokott, háborús megoldási mód jához, s felhagyjanak a hidegháború körülményes és nehézkes múfajával. Mi sem bizonyítja ezt jobban, mint a fegyverkezési verseny folytatódása. Valójában továbbra is azon vannak, hogy a kölcsönös tömeges megsemmisítés veszélyét meghaladják, s az ellenséget úgy győzhessék le katonailag, hogy közben ók maguk ne szenvedjenek el viselhetetlen károkat. Ezért könnyen meglehet, hogy a hidegháborúk kora végül is csak egy történelmi epizód lesz a világháborúk két nagy korszaka között.

\section{A hidegháború fogalmi értelmezésének jelentôsége és problémái}

A nemzeti érdekeik ütközése miatt az államok a történelem során mindig is folytattak a hidegháborúhoz hasonló jellegű küzdelmeket. Azok azonban a legtöbb esetben mindössze a hatalmi vetélkedésük háborúban kulmináló megharcolásának az előkészítései voltak. Az 1946 és 1991 közti időszakra datálható előző hidegháborút az tette minőségileg új, önmagában is definiálandó történelmi jelenséggé, hogy nem előkészítő jellegú volt, hanem maga volt a globális nagyhatalmi küzdelem.

Bár a tudomány az előző hidegháború alapos el méleti elemzésével még adós, megállapítható, hogy az egy komplex folyamat volt, amely sokféle konkrét, de egymással szorosan összefüggő formát öltött, és 


\section{Külïgyi Szemle}

kiterjedt a nemzetközi viszonyok minden szférájára. A súlyponti ele me a stratégiai-katonai szembenállás, a fegyverkezési verseny, a geo politikai befolyás kiterjesztése, a szemben álló szövetségi rendszerek léte, illetve a regionális és helyi fegyveres konfliktusokba való nagyhatalmi beavatkozás volt. Azonban távolról sem csak ezek határozták meg, hanem más szférákban is zajlott az összeütközés. Ilyen ïgyekhez tartozott a gazdasági és technológiai verseny; a kettéosztott világgaz dasági szerkezet; a kétosztatú technológiai szféra; az életszínvonal, az életmód és a szociális ellátások terén folyó versengés; az intellektuális, oktatási, tudományos, kulturális szférában, valamint az értékrendek és az ideológia terén való szembenállás; a másik félnek és a belső stabilitásának a megingatására való törekvés, a belügyeikbe való beavatkozás, stb.

Az elméleti általánosítás szempontjából az a legfontosabb, hogy a hidegháború totális, komplex és átfogó jellegú történelmi jelenség, amely kiterjed minden szférára. Fő mozgatója a vezető szuperhatalmaknak a - kényszerúen viszonylag békés - reálpolitikai vetélkedése a globális dominanciáért. Ugyanakkor ennek pőre beismerése rontaná az állami, össztársadalmi erőkifejtés hatékonyágát, az erkölcsi-politikai elfogadottságát, ezért a küzdelmet berendezkedési, értékrendi, ideológiai harcként tüntetik fel. Két állam berendezkedése és hivatalos értékrendje - történelmi, társadalmi, civilizációs és más okokból - soha sem teljesen azonos, így az értékrendi eltérések kétség telenül léteznek. Azok szelektív módon történő, kiemelkedő fontossá gúvá transzformálása viszont nem más, mint a hidegháborús politika egyik legfontosabb eszköze. A nyilvánvaló politikai célja a másik fél démonizálása és a szüikséges saját belső társadalmi mobilizáció és erőforrás-koncentráció biztosítása a hosszú küzdelem egész idejére.

Ugyanakkor a hidegháború totalitásán belüil a különböző szférák súlya eltérő és időben változó, csakúgy, mint a földrajzi hadszínte rek kiterjedése és relatív fontossága. E változások megnehezítik a hidegháború felismerését, illetve annak a történelmi pillanatnak a kijelölését, amelyben a különböző szférákban és térségekben a nagyhatalmak közötti állandó és természetes vetélkedések egységes, koherens 
rendszerré, azaz új minőséggé, hidegháborúvá állnak össze. A hideg háború elemzésének éppen ez az egyik legnagyobb kihívása, és azért is kulcsfontosságú, mert a hidegháború kezdetével az egész nemzet közi rendszer működése és minden állam érdekérvényesítésének a közege, feltételrendszere is minőségileg új kontextusba kerül, ami a nemzetközi viszonyok és külpolitikák fundamentális újragondolását teszi szükségessé.

Ha analógiával akarjuk megvilágítani e jelenséget, akkor a megér tést legjobban az mozdítja elő, ha a világháborúkkal vonunk párhuzamot. Az eddigi két világégés sajátosságaiban jelentős eltérések mutatkoztak, de még az axiomatikus, a világháborúnak precíz tudományos definíciót nem adó gondolkodás esetén is világos, hogy a meghatározó jellemzőik alapján azonos kategóriába sorolhatók, amely a nembeli lényegüket megragadva felülemelkedik az eltéréseiken. Történelmi analógia, hogy az elsô világháborút mindaddig egyedi jelenségnek - az angol nyelvterületen „nagy háborúnak” - nevezték, amíg a másodiknak a kitörésével világossá nem vált, hogy a nagyhatalmi konfliktusok globális háborús megvívásának új minôségérôl van szó.

Hasonló a helyzet a hidegháború esetében is. Amíg csak egy for dult elő, ez a nagyhatalmi küzdelmi forma egyedinek tűnt, s csak most, amikor újra hasonlóan totális, komplex, átfogó és globális, viszonylag békés nagyhatalmi küzdelem bontakozik ki, merül fel az a tudományos kérdés, hogy valójában nem egy új minőséggel állunk-e szemben. A válaszom erre igenlő, s ennek alapján szüikségesnek tartom a világháborúk sorszámozásának (I., II.) mintájára a hidegháborúk sorszámozásának a bevezetését is.

\section{A második hidegháború kezdete és elsố szakasza}

A fentiek alapján küiön kihívást jelent a hidegháborúk kezdetének a pontos meghatározása, illetve az alakulásuk, menetük precíz szakaszolása.

Az első hidegháború kezdetét általában 1946 tavaszához, George F. Kennan Moszkvában szolgáló amerikai diplomata február 22-i 


\section{Külïgyi Szemle}

„hosszú táviratához”, illetve Winston S. Churchill volt brit minisz terelnök március 5-i „fultoni beszédéhez” kötjük (Kennan, 1946; Churchill, 1946). E külpolitikai dokumentumok nem fókuszáltak a hidegháború fogalmára, viszont alaposan leírták a nyugati-szovjet szembenállás átfogó, komplex, totális és globális jellegét. Mindezt a nyugati szakirodalom és politika a Szovjetunió második világháborút követő agresszív kelet-közép-európai stratégiai, geopolitikai térfog lalására történt reagálásnak tekinti, s a hidegháború kezdetének ódi umát ezzel a keleti hatalomra terheli. A terminus viszont csak jóval később nyert polgárjogot, és kezdődött meg az általános használata.

Ma is hasonló jelenséggel találkozunk. Az Amerikai Egyesuilt Államok 2017. december 18-án közzétett Nemzetbiztonsági stratégiája adta az első szisztematizált összegzést, amely leírta az amerikai-kínai (és amerikai-orosz) szembenállás totális, átfogó, komplex és globális jellegét (Trump White House Archives, 2017). Ezt vitte tovább 2021. március 3-án a Joe Biden vezette kormány ideiglenes straté giai dokumentuma is (The White House, 2021a). A nyugati szakiroda lom és politika e megközelítést a Krím félsziget 2014-es Oroszor szághoz csatolásával, de főként Kína globális nagyhatalmiságának az öntudatos meghirdetésével támasztja alá. Ez utóbbi szisztematizált, programszintű kifejtése Hszi Csin-ping kínai pártfőtitkár-államfőnek a Kínai Kommunista Párt (KKP) 2017. október 18-án kezdődött 19. kongresszusán elmondott beszédében található (Xi, 2017). Ezzel az új hidegháború elindításának ódiuma a szakirodalomban újra a két keleti nagyhatalmat terhelheti, miközben magának a terminusnak egyelőre vitatott az alkalmazása. ${ }^{2}$

2 Az elemzés során nem hagyható figyelmen kívül, hogy napjaink világában mindenki információs - média-, tudományos és elemzői - buborékban él. A nyugati megközelítés azonban nem univerzális és kizárólagos, hiszen több információs buborék is él egymás mellett a világban. A hidegháborúk okainak értelmezésében is jelentősen eltérő értékelések dominálnak a nyugati, a kínai, az orosz és más szakirodalmakban. Mivel mi Magyarországon óhatatlanul is a nyugati információs buborékban élüink, e tanulmány sem szakadhat el attól, de azt szem előtt kell tartanunk, hogy egyik értelmezési közeg sem tekinthető sem elfogulatlannak, sem tudományosan objektívnek, sem garantáltan helytállónak. 
Az új hidegháború legátfogóbb nyugati koncepcionális felfogása az amerikai szakirodalomban mutatható ki. Az USA-ban lényegében politikai konszenzust élvező - bár magát a terminust kerülő - hidegháborús program az egyik, önmagát megnevezni nem kívánó, korábbi rangos kormányzati tisztségviselőnek az Atlantic Council által publikált tanulmányában olvasható (Anonymus, 2021). Ugyanakkor a szakmai ellenvéleményeket tükröző koncepciók is nyilvánosságra kerülnek, de azok a politikára jelenleg minimális hatást gyakorolnak (Swaine, Lee és Odell, 2021; Larison 2021). ${ }^{3}$

Az utóbbi néhány év fejleményei alapján a második hidegháború kezdete nagyjából 2018 elejére datálható, mivel a globális nagyhatalmi vetélkedés akkor indult el a szemünk láttára a totális, komplex és átfogó szisztémává válás útján, amely azóta egyre gyorsuló ütemben válik meghatározó momentummá a nemzetközi folyamatokban. Ugyanakkor az is látható, hogy az új hidegháború még csak a kezdeti, kiformálódó szakaszában jár. Annak vagyunk a szemtanúi, hogy hogyan zajlik a két szemben álló oldalnak - egyrészt az USA vezette (Európa hatalmai, Japán és a többi angolszász ország alkotta) Nyugatnak, másrészt a Kína és Oroszország, valamint a hozzájuk kötődő államok kisebb csoportjaival fémjelzett Keletnek - az újra-, illetve megszerveződése és a hosszú távú küzdelem megvívására való alkalmassá tétele.

A gyakorlati politika szintjén e folyamat eddigi csúcspontjait az amerikai elnök 2021. június 11-16. közötti európai körútja, illetve a 2021. június 28-án elektronikus formában megtartott kínai-orosz csúcstalálkozó jelentette. A G7-, a NATO-és az USA-EU-csúcsértekezletek dokumentumai rögzítették a második hidegháború nyugati oldalának a szorosabb összefogását, körülhatárolták a szembenállási szférákat, illetve ennek logikus reakciójaként a kínai-orosz csúcstalálkozóhoz kapcsolódó dokumentum is hasonló értelmet nyert (European Council, 202la; North Atlantic Treaty Organization,

3 Biztosra vehető, hogy a keleti nagyhatalmak szakmai köreiben és készültek hasonló átfogó tanulmányok, de a kínai és az orosz külpolitika-formálás hagyományai szerint valószínű, hogy a külön munkacsoportok által készített, a politikai döntéshozatalt megalapozó koncepcionális munkák titkosak, és még évekig azok is maradnak. 


\section{Külïgyi Szemle}

2021; European Council, 2021b; REV, 2021a; REV, 2021b; REV, 2021c; Dieter, 2021; Yang és Chen, 2021; Kremlin, 2021).

Tekintettel arra, hogy már a kezdeti szakaszban milyen hatalmas erők lendültek mozgásba mindkét oldalon, igen kicsi az esély arra, hogy az új hidegháború néhány éven belül lezáruljon. Várhatóan ez is több szakaszból fog állni, miként az előző is, ezért a következő években kulcsfontosságú lesz az események dinamikájának a nyomon követése, a fordulatok, a keletkező szakaszhatárok felismerése és helyes értelmezése.

\section{A második hidegháború kezdeti szakaszának legfontosabb frontvonalai és hadszínterei}

Az új hidegháború egymással szoros összefüggést mutató fő tartalmi frontvonalai - szisztematikus fontossági sorrendben - az alábbiakban határozhatók meg:

1. A gazdasági és technológiai verseny, amely magában foglalja a kereskedelmi háborúkat, a befektetések nemzetbiztonsági okokra történő hivatkozással való korlátozásait, a pénzügyi szférában folyó küzdelmeket, a technológiai versengést és a gazdasági korlátozó intézkedések, szankciók rendkívül széles tárházát. Mindez a világgazdasági intézmény-és szabályrendszer, a termelési és értékláncok, valamint a globális technológiai keretek újbóli kettészakítását is kockáztatja. E versengésben mindkét oldal célja az új, digitális szakaszba lépő globalizáció fölötti kontroll megszerzése, a szemben álló oldal fejlődésének a megnehezitése, alárendelt gazdasági helyzetbe hozása. Az új hidegháborúnak - szemben az előzôvel - ez a prioritásos területe, amely jórészt meghatározza a folyamatok dinamikáját. Különösen jól látható ez a felek hosszú távra szóló törvényho zása terén (Menendez, 2021; Chen és Liu, 2021).

2. A geopolitikai befolyásépítésben folyó versengés új hangsúlyaként előtérbe kerülnek az elsődlegesen gazdasági és csak másodlagosan geopolitikai konzekvenciájú eszközök, köztük 
kiemelten a kínai Övezet és Út Kezdeményezés (Belt and Road Iniliative, BRI), illetve a nyugati reagálásként elindított ellenprojektek, s föként a G7 országok Építsünk Vissza Jobban (Build Back Better, B3W) kezdeményezése (Kusai, 2020b; Menendez, 2021; European Council, 2021a).

3. A katonai szembenállás, fegyverkezés és a nemzetbiztonság hagyományos és új tényezői felölelik a katonai és titkosszolgálati kapacitások fejlesztésének minden szektorát - a stratégiai és taktikai fegyverzetektől a kiber- és ürhaderőkön keresztül a technikai és humán hírszerzésig és a fedett akciókig. A katonai elrettentés és erőfitogtatás minden eszközének az alkalmazása jellemző: a flottatüntetésektől a szárazföldi és légierők de monstratív akcióiig, hadgyakorlataiig, sôt a szemben álló felek környezetében, illetve egyes regionális és helyi válsággócokban történő konkrét fegyveres beavatkozásokig. A hibrid hadviselés és a titkosszolgálatok küzdelmeinek a folyamatos erősödésé re is egyre több jel utal. A szövetségépítés, a bekerités, feltartóztatás és visszaszorítás stratégiája, illetve az abból való kitörési törekvés újra növekvő fontosságúvá válik. Továbbra is jelentős szerep jut a hidegháború eszközeként a kemény erô (hard power) mutatásának és alkalmazásának, bár az az előző hidegháborúnál most hátrébb rangsorol az eszköztárban (Anonymus, 2021; Haass és Kupchan, 2021; Gyarmati, 2021).

4. A belsô gazdasági, társadalmi, ideológiai és politikai stabilitás, kohézió felértékelődése, külön frontvonallá válása is zajlik. A hidegháborús főszerelók mindegyike jelentős belső kihívásokkal küzd. Az Amerikai Egyesült Államokat, Európa vezető hatalmait, Japánt, illetve Kínát és Oroszországot is sokrétegủ belső ellentmondáshalmaz feszíti. Kiemelkedő kérdés, hogy miként, mennyire és mikorra sikerül a belső helyzetük stabilizálása, s így az egyes erőközpontok mekkora külső erőkifejtésre képe sek. A hátország megerősitése elvezet a belpolitikai tér dominálásának az igényéhez, amely a demokratikus országokban a rendpártiság erősödését, a véleményalkotás monopolizálására 


\section{Külïgyi Szemle}

való törekvéseket, az autoriter államokban pedig az ellenzékkel szembeni kemény fellépést vonja maga után. Igy a hidegháborús küzdelem egyik természetes frontja az ellenoldal belső folyamatainak a befolyásolása, amelyet a nagyhatalmak teljes erejükkel végeznek (REV, 2021a; $R E V, 2021 \mathrm{c})$.

5. A puha erô (soft power), az intellektuális, szellemi, média- és ideológiai befolyásépítés, illetve konfrontáció a második hidegháború jelentős frontvonala, amely szorosan összefügg a belpolitikai, ideológiai küizdelmekkel és tendenciákkal is. Az új hidegháború egyik első jelentős nyugati intellektuális aktusa is a szellemi-ideológiai konfrontáció szférájára jutott (Benner, Gaspers, Ohlberg, Poggetti és Shi-Kupfer, 2018). ${ }^{4}$

6. A globális erőviszonyok, a világrend, a nemzetközi rendszer és a globális kormányzás tekintetében a kibontakozó új hidegháború nem más, mint az „Amerika vezette, szabályokon alapuló, liberális világrend”, a „Pax Americana”, az unipoláris amerikai dominancia - a 2008-2009-es világgazdasági válságtól kezdve felszínre törő és a 2020-2021-es koronavírus-világjárvány által felerősített - súlyos, rendszerszintű válságának a következménye. Mindez mára a stratégiai, biztonsági szférában a globális intézményrendszer súlyos diszfunkcióihoz, szinte teljes paralíziséhez, a globális problémák (járványkezelés, klímaváltozás, a szegénység felszámolása stb.) terén pedig súlyos hatékonyságvesztéséhez vezetett. Nemzetközi vonatkozásban a második hidegháború olyan globális nagyhatalmi küzdelem, amely hosszú távon a jelenlegi világrend teljes összeomlását eredményezheti, egy új világháború előszobájává válhat, illetve akár elvezethet egy, a tartalmában multipoláris, a formájában pedig multilaterális új világrend kialakulásához is (Fishman, 2020; Gyarmati, 2021; Kusai, 2020a; Swaine, Lee és Odell, 2021).

4 Ez közvetlenül kihat a nemzetközi viszonyok tudományos elemzésére, a többi nagyhatalommal foglalkozó kutatásokra és kutatókra is, amennyiben a nyugati ol dalon visszatér a mccarthyzmus, a keleti oldalon pedig kiteljesedik a kormányzati és pártkontroll. Mindkét jelenség az objektív, a propagandisztikus kirohanásoktól mentes kutatómunka növekvő gátjaként tűnik fel. 
Az új hidegháború földrajzi hadszínterei eltérő fontossági sorrendet, új szerkezetet és - jórészt a gazdasági globalizáció miatt - sokkal szorosabb összekapcsolódásokat mutatnak, mint az előző idején:

1. A főhadszíntérré az Indo-csendes-óceáni nagytérség lépett elö, ahol a hidegháború főszereplői, azaz az Egyesült Allamok (és ázsiai szövetségesei), illetve Kína - és másodlagosan Oroszország - közvetlenüil uitköznek.

2. A legfontosabb mellékhadszíntérként szorosan követi a föhad színteret az észak-atlanti-eurázsiai nagytérség, ahol az USA és európai szövetségesei Oroszországgal közvetlenül, Kínával pedig áttételesen állnak szemben.

További mellékhadszínterek:

3. a Közel-és Közép-Kelet;

4. Afrika;

5. Latin-Amerika;

6. az Arktisz;

7. az Antarktisz; illetve egyre inkább

8. a világür és

9. új, virtuális hadszíntérként a kibertér is.

A hadszínterek fontossági sorrendje összhangot mutat a tartalmi frontvonalak súlypontjainak az eltolódásával, és tükrözi azt, hogy az USA vezette nyugati erőcentrum ma Kínában látja a fő rendszerszintủ ellenfelet, kihívót, amely az össznemzeti gazdasági, technológiai potenciálja mellett stratégiai és geopolitikai tekintetben is számottevó erôt képvisel, továbbá ideológiai-politikai és világrendi szempontból is alternatív nagyhatalomnak tételezi magát. A Nyugat Oroszországot viszont nukleáris szuperhatalomként leginkább a stratégiai-katonai és a geopolitikai szférában tekinti jelentős ellenfélnek.

A második hidegháború strukturális jellemzői jól mutatják, hogy a lényegét tekintve azonos fogalmi kategóriába tartozik az első hidegháborúval, de több aspektusban is jól elküilönülő sajátosságokat mutat. 


\section{Külïgyi Szemle}

\section{Következtetések, dilemmák és kérdések}

A 2018 óta eltelt szűk három év alatt nagyjából kirajzolódtak a második hidegháború fő paraméterei, és egyértelműen beléptüink annak a kezdeti szakaszába. Ugyanakkor felszínre kerültek olyan stratégiai súlyú dilemmák is, amelyek megoldása még sokat módosíthat a lefolyásán.

Az már nyilvánvaló, hogy a meghatározó amerikai politikai körökben konszenzus alakult ki a globális dominancia bármi áron való megőrzésének, illetve visszaszerzésének a szükségességéről. Egyetértés van abban is, hogy a fő rendszerszintű ellenfél Kína, a másik geopolitikai ellenfél pedig Oroszország. Donald Trump és Joe Biden kormányának a fő célkitűzéseiben nincsenek alapvető eltérések, a hidegháború megvívásának a módjában viszont számos különbség mutatkozik. A Biden-kormány, elődjétől eltérően, nem unilateralista alapon, hanem a nyugati nagyhatalmi szövetséget a saját vezetése alatt újraszervezve, az amerikai kivételesség elvi alapjain kívánja az új hidegháborút megvívni.

Kiderült, hogy Kína nem szándékozik feladni sem a saját, unikalizmuson alapuló berendezkedését, sem a világrend átalakítását célzó, alternatív globális nagyhatalmi programját. Oroszország sem mutat hajlandóságot a rendszerszintű belső átalakulásra és a nagyhatalmisága feladására.

Ezzel kialakult a második hidegháború két markánsan szemben álló pólusa: az USA vezette nyugati nagyhatalmi kör az egyik oldalon, illetve Kína és Oroszország valamilyen formájú konfigurációja a másikon. Mivel a két fél értékrendje és érdekei valószínútlenné tesznek minden lényeges kompromisszumot, azzal kell számolni, hogy az új hidegháború tartósan velünk marad, és a következő időszak meghatározó nemzetközi tényezője lesz.

A gazdasági globalizáció és a társadalmi globalizmus, a kölcsönös függőségek hálójának mai szintjén kérdéses azonban, hogy e szálak drasztikus szétszaggatása kivitelezhető-e egyáltalán, illetve milyen mértékű károkat okozna a szemben álló oldalaknak, és a 
negatív következményei társadalmilag és belpolitikailag elviselhetők maradnának-e számukra. Különösen erós dilemmákat jelent ez Ame rika európai és ázsiai nagy-, közép- és kishatalmi szövetségeseinek. Az európaiak számára a nyugati szövetségi rendszer szorosabbra vonásának a mértéke ugyancsak problémás, mivel az az óhajtott európai stratégiai autonómia további szúküilését vetíti előre. Ezeket az aggályokat az a kérdés is növeli, hogy egy értelemszerủen hosszú távú hidegháború kezdetén, az erôs amerikai belpolitikai megosztottság körülményei között mennyire lesz tartós, több választási cikluson átívelő a Biden-kormány jelenlegi taktikai irányvonala.

Eközben a másik térfélen is markáns dilemmák sora vetődik fel. A legnagyobb közülüik az, hogy a nyugati nyomás által a „hátukat egymásnak vető stratégiai partnerségbe” szorított Kína és Oroszország általános stratégiai érdekközössége mennyire és meddig képes felülírni a meglévő partikuláris érdekeltéréseiket, azaz milyen konkrét konfigurációt tud a két hatalom kialakítani egymással (Global Times, 2021). Felmerül a kölcsönös bizalom kérdése is, hiszen - történelmi okokból - a kínai gazdasági és politikai elitben számottevőek az Ame rika-barát, az oroszban pedig az Európa-barát attitűdök, amelyek mögött jelentős konkrét gazdasági érdekeltségek is meghúzódnak. Egyelőre nem látszik jele annak, hogy a Biden-Putyin-csúcstalálkozón amerikai részről komoly alkuajánlat merüilt volna fel a kínai-orosz tengely megbontása céljából, de a későbbiekben ilyesmit egyik keleti nagyhatalom vonatkozásában sem lehet teljesen kizárni. Ugyanakkor az is nyilvánvaló, hogy ez utóbbiaknak hosszú távon csak közösen van esélyüik az új hidegháborúban, hiszen az egyikük teljes veresége, kiesése vagy netán pálfordulása esetén a másik képtelen lenne szembe szállni az Amerika vezette Nyugat egyesített, koncentrált nyomásával.

A nyugati érdek-, érték-, integrációs és szövetségi körbe tartozó kisebb európai államok - köztük Magyarország - számára a második hidegháború kezdeti szakasza teljesen új globális és regionális helyze tet teremt. Nemzeti érdekeik érvényesítése, az új küilső közegben való sikeres navigálás számos stratégiai és taktikai kérdést vet fel, amelyek alapos tanulmányozást és mérlegelést érdemelnek. Egyrészt elemezni 


\section{Külïgyi Szemle}

és értelmezni kell a hidegháborúnak mint specifikus történelmi je lenségnek a törvényszerűségeit, dinamikáját; másrészt szükség van arra, hogy naprakészen kövessék és objektíven, realistán, az ideológiai torzításoktól, szólamoktól mentesen értékeljék a kibontakozóban lévő második hidegháború minden rezdülését és fejleményét, ami segíti a külpolitikai mozgástér felmérését és kihasználását. De nélküilözhetet len az is, hogy az említett kérdésekről komoly szakmai vitákat foly tassanak.

\section{I rodalomjegyzék}

Anonymus (2021). The Longer Telegram: Toward a New American China Strategy. Allantic Council, Strategic Papers, January, 2021. A leöltés ideje: 2021. június 17. https:/www.atlanticcouncil.org/wp-content/ uploads/2021/01/The-Longer-Telegram-Toward-A-New-AmericanChina-Strategy.pdf.

Benner, Thorsten, Gaspers, John, Ohlberg, Mareike, Poggetti, Lucrezia és Shi-Kupfer, Kristin (2018). Authoritarian Advance. Responding to China's Growing Political Influence in Europe. GPPI-MERICS Report. A letöltés ideje: 2021. június 17. https://merics.org/sites/default/files/2020-04/ GPPi_MERICS_Authoritarian_Advance_2018_1.pdf.

Chen Qingqing és Liu Xin (2021). China's Newly Passed Anti-Foreign Sanctions Law to Bring Deterrent Effect Against Western Hegemony. Global Times. A letöltés ideje: 2021. június 17. https://www.globaltimes. cn/page/202106/1225911.shtml.

Christensen, Thomas J. (2021). There Will Not Be a New Cold War. The Limits of U.S.-Chinese Competition. Foreign Affairs. A letöltés ideje: 2021. június 17. https://www.foreignaffairs.com/articles/unitedstates/2021-03-24/there-will-not-be-new-cold-war.

Churchill, Winston S. (1946). The Sinews of Peace ('Iron Curtain Speech'). International Churchill Sociely. A letöltés ideje: https://winstonchurchill. org/resources/speeches/1946-1963-elder-statesman/the-sinews-ofpeacel.

Dieter, Heribert (2021). First Summit of the Anti-China Coalition. Cornwall G7 Highlights BRICS Weakness. Sliftung Wissenschaft und Politik. German Institule for International and Security Affairs. A letöltés ideje: 
2021. június 17. https://www.swp-berlin.org/publications/products/ comments/2021C36_G7 Summit Cornwall.pdf.

Dupont, Alan (2020). The US-China Cold War Has Already Started. The Diplomat. A letöltés ideje: 2021. június 17. https:/thediplomat. com $/ 2020 / 07 /$ the-us-china-cold-war-has-already-started/.

European Council (2021a). Carbis Bay G7 Summit Communiqué: Our Shared Agenda for Global Action to Build Back Better. A letöltés ideje: 2021. június 17. https://www.consilium.europa.eu/media/50361/carbisbav-g7-summit-communique.pdf.

European Council (2021b). EU-US Summit Statement Towards a Renewed Transatlantic Partnership. A letöltés ideje: 2021. június 17. https://www. consilium.europa.eu/media/50443/eu-us-summit-joint-statement-15june-final-final.pdf.

Fishman, Edward (2020). The World Order Is Dead. Here's How to Build a New One for a Post-Coronavirus Era. Politico. A letöltés ideje: 2021. június 17. https://www.politico.com/news/magazine/2020/05/03/thepost-coronavirus-world-order-230042.

Global Times (2021). China-Russia Ties Assure Global Strategic Balance. A letöltés ideje: 2021. június 17. https://www.globaltimes.cn/ page/202105/1224483.shtml.

Guetta, Bernard (2021). Kínával, Erdogannal és Putyinnal szemben alakul a közös európai külpolitika. Magyar Narancs. A letöltés ideje: 2021. június 17. https://magyarnarancs.hu/publicisztika/kinaval-erdogannales-putvinnal-szemben-alakul-a-kozos-europai-kulpolitika-238244.

Gyarmati István (2021). Jó lenne háború nélkül túl lenni a XXI. század legnagyobb kihívásán. Heli Világgazdaság. A letöltés ideje: 2021. június 17. https://hvg.hu/360/20210616_Gvarmati_Istvan_Kina_Oroszorszag Nyugat.

Haass, Richard N. és Kupchan, Charles A. (2021). The New Concert of Powers. How to Prevent Catastrophe and Promote Stability in a Multipolar World. Foreign Affairs. A letöltés ideje: 2021. június 127. https:/Wwww. foreignaffairs.com/articles/world/2021-03-23/new-concert-powers.

Hegyi Gyula (2021a). A Nyugat elképesztő hibát vét, ha szorosabb szövetségbe kényszeríti Oroszországot és Kínát.Azonnali.A letöltés ideje: 2021.június 17. https:/azonnali.hu/cikk/20210325_a-nvugat-elkepeszto-hibat-vetha-szorosabb-szovetsegbe-kenvszeriti-oroszorszagot-es-kinat. 


\section{Külïgyi Szemle}

Hegyi Gyula (2021b). Ne hagyjuk, hogy belerángassanak minket az új hidegháborúba! Azonnali. A letöltés ideje: 2021. június 17. https:/azonnali. hu/cikk/20210608 ne-hagvjuk-hogy-belerangassanak-minket-az-ujhideghaboruba.

Kennan, George F. (1946). 'Long Telegram'. Wilson Center, Digilal Archive. A letöltés ideje: 2021. június 17. https:/digitalarchive.wilsoncenter.org/ document/116178.pdf.

Kremlin (2021). Joint Statement of the Russian Federation and the People's Republic of China on the Twentieth Anniversary of the Treaty of Good Neighbourliness and Friendly Cooperation between the Russian Federation and the People's Republic of China. 28 June 2021. A letöltés ideje: 2021. június 29. http://static.kremlin.ru/media/events/files/en/Bo3 RF3JzGDvMAPjHBQAuSemVPWTEvb3c.pdf.

Kusai Sándor (2021). Hogyan lett az új hidegháborúból globális vakcinaháború? Index. A letöltés ideje: 2021. június 17. https://index. hu/velemenv/2021/02/20/hogvan-lett-az-uj-hideghaborubol-globalisvakcina-haboru- - .

Kusai Sándor Zoltán (2020a). Kína részvételének sajátosságai és ellentmon dásai a világkormányzás átalakulásában. In P. Szabó Sándor és Hor váthné Varga Polyák Csilla (szerk.), Lehetöségek és kihívások a magyar kinai kapcsolatok terülelén (63-76. o.). A letöltés ideje: 2021. június 17. https:/nkerepo.uni-nke.hu/xmlui/bitstream/handle/123456789/16046/ web_PDF_Lehetosegek kihivasok magvar kinai kapcsolatok. pdf? sequence $=1$.

Kusai Sándor Zoltán (2020b). Kína Új Selyemút Kezdeményezése és kezelésének kihívásai. In Ágh Attila és Káncz Csaba (szerk.), Változó világrend. A bizonylalanság kora a nemzelközi politikában (203-223. o.)

Larison, Daniel (2021). 'The Longer Telegram' Is a Recipe for Costly Failure. The American Conservalive. A letöltés ideje: 2021. június 17. https:// www.theamericanconservative.com/state-of-the-union/the-longertelegram-is-a-recipe-for-costly-failure/.

Lehoczki Noémi (2021). Az új hidegháború - Kapitalizmus kínai karakterekkel. Mérce. A letöltés ideje: 2021. június 17. https://merce. hu/2021/01/08/az-uj-hideghaboru-kapitalizmus-kinai-karakterekkel/.

Lóránt Károly (2021). Kínai álom. Magyar Hirlap. A letöltés ideje: 2021. június 17. https://www.magvarhirlap.hu/velemeny/20210531-kinai-alom. 
Menendez, Robert (2021). A Bill to Address Issues Involving the People's Republic of China. U.S. Senate. A letöltés ideje: 2021. június 17. https://www.foreign.senate.gov/imo/media/doc/DAV21598\%20-\%20 Strategic $\% 20$ Competition $\% 20$ Act $\% 20$ of $\% 202021$.pdf.

Munk Veronika (2021). Az amerikai külügyminiszter a Telexnek: Moszkva és Peking aktívan ássa alá a demokráciát Közép-Európában. Telex. A letöltés ideje: 2021. június 17. https://telex.hu/kulfold/2021/04/29/ amerikai-kulugvminiszter-a-telexnek-moszkva-es-peking-aktivanassa-ala-a-demokraciat-kozep-europaban.

$\mathrm{Ni}$, Vincent (2021). Failure to Improve US-China Relations 'Risks Cold War', Warns Kissinger. The Guardian. A letöltés ideje: 2021. június 17. https:// www.theguardian.com/us-news/2021/mav/01/us-china-doomsdaythreat-ramped-up-by-hi-tech-advances-savs-kissinger.

North Allantic Treaty Organization (2021). Brussels Summit Communiqué.

A letöltés ideje: 2021. június 17. https://www.nato.int/cps/en/natohq/ news 185000. htm.

REV (2021a). Joe Biden Press Conference Transcript after Meeting with Putin. A letöltés ideje: 2021. június 17. https://www.rev.com/blog/ transcripts/joe-biden-press-conference-transcript-after-meetingwith-putin.

REV (2021b). Joe Biden Speaks to Press before Leaving Geneva Transcript. A letöltés ideje: 2021. június 17. https:/www.rev.com/blog/transcripts/ joe-biden-speaks-to-press-before-leaving-geneva-transcript.

REV (2021c). Vladimir Putin Press Conference Transcript After Meeting with Biden in Geneva. A letöltés ideje: 2021. június 17. https:/www. rev.com/blog/transcripts/russian-president-vladimir-putin-pressconference-transcript-after-meeting-with-biden-english-translation.

Swaine, Michael D., Lee, Jessica J. és Odell, Rachel E. (2021). Toward an Inclusive \& Balanced Regional Order. A New U.S. Strategy in East Asia. Quincy Instilute for Responsible Stalecraft. Quincy Paper No. 5. A letöltés ideje: 2021. június 17. https:/quincvinst.org/wp-content/ uploads $/ 2021 / 02 / \mathrm{A}-\mathrm{New}$-U.S.-Strategy-in-East-Asia.pdf.

The While House (2021a). Interim National Security Strategic Guidance. March, 2021. A letöltés ideje: 2021. június 17. https://www.whitehouse. gov/wp-content/uploads/2021/03/NSC-1v2.pdf. 


\section{Külïgyi Szemle}

The While House (2021b). Remarks by President Biden in Address to a Joint Session of Congress. A letöltés ideje: 2021. június 17. https:// www.whitehouse.gov/briefing-room/speeches-remarks/2021/04/29/ remarks-by-president-biden-in-address-to-a-joint-session-ofcongress.

Trump While House Archives (2017). National Security Strategy of the United States of America. A letöltés ideje: 2021. június 17. https:// trumpwhitehouse.archives.gov/wp-content/uploads/2017/12/NSSFinal-12-18-2017-0905.pdf.

Xi Jinping (2017). Secure a Decisive Victory in Building a Moderately Prosperous Society in All Respects and Strive for the Great Success of Socialism with Chinese Characteristics for a New Era. Xinhuanet. A letöltés ideje: 2021. június 17. http://www.xinhuanet.com/english/ download/Xi Jinping's report at 19th CPC National Congress.pdf.

$\mathrm{Xi}$ Jinping (2018). The Governance of China II. Beijing: Foreign Languages Press.

Yang Sheng és Chen Qingqing (2021). China, Russia Eye Fixing 'Global Disorder' Amid US Withdrawal. Global Times. A letöltés ideje: 2021. június 17. https://www.globaltimes.cn/page/202105/1224481.shtml.

Zakaria, Fareed (2021). Opinion: The Pentagon Is Using China As an Excuse for Huge New Budgets. The Washinglon Post. A letöltés ideje: 2021. június 17. https://www.washingtonpost.com/opinions/ the-pentagon-is-using-china-as-an-excuse-for-huge-newbudgets/2021/03/18/848c8296-8824-11eb-8a8b-5cf82c3dffe4 story.html. 